\title{
THE INTERACTION OF POLYMER SURFACES WITH BLOOD
}

\section{T. BEUGELING}

Department of Chemical Technology, Biomaterials Section, Twente

University of Technology, ENSCHEDE, The Netherlands

\section{SYNOPSIS}

Some general aspects of the interaction of foreign materials with blood are summarized. The role of protein adsorption in this interaction is briefly discussed. In an attempt to produce more stable antithrombogenic surface coatings than the well-known heparin-bonded surfaces, a method is described in which a high-molecular-weight polyelectrolyte is bound to polymer surfaces. In vitro experiments carried out with freshly drawn human blood show a reduced platelet adhesion on such surfaces.

\section{INTRODUCTION}

Two important aspects of the interaction of foreign materials with blood are platelet adhesion and blood coagulation. These processes are dependent on surface properties of the material, on flow conditions, and on the way in which the initial blood-material contact is brought about $[1,2]$. When a material is exposed to blood, the first event which takes place is the adsorption of proteins from the blood onto the material surface. Upon adsorption of these proteins, the surface of the material will be altered and the subsequent events will be determined by the modified surface.

A schematic representation of the phenomena which occur when a foreign material is contacted with blood is shown in Figure 1. It must be emphasized that the intrinsic coagulation process can be initiated either on the surface of aggregating platelets [3] or by activation of factor XII on the foreign material. During the coagulation process thrombin is formed. Thrombin, being a release inducer, also causes platelet aggregation. Thus in later stages of platelet adhesion/aggregation and intrinsic coagulation there will be a mutual interaction between these processes. Therefore a candidate thromboresistant material must reduce both platelet adhesion and the contact activation of factor XII.

\section{ROLE OF PROTEIN ADSORPTION}

There is evidence that platelet adhesion is promoted when fibrinogen and/ or $\gamma$-globulin are adsorbed from the blood onto foreign surfaces [4-11]. The 


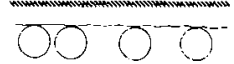

3

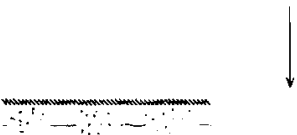

โa
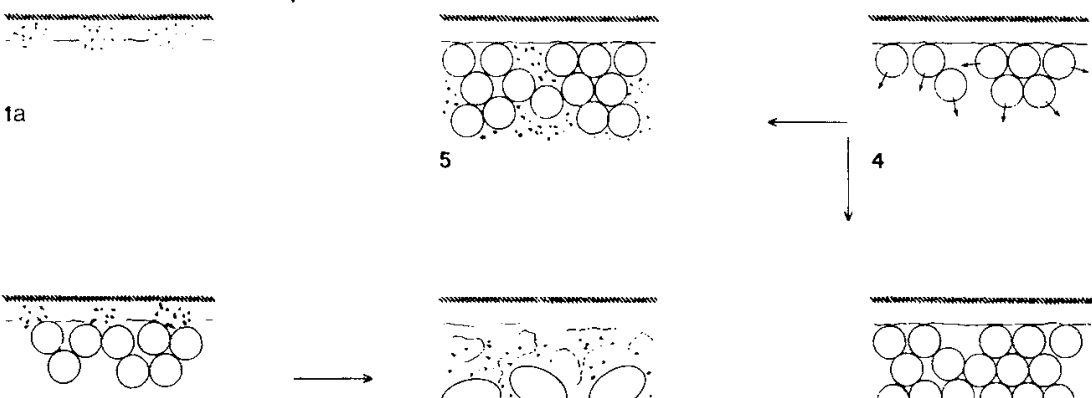

1b

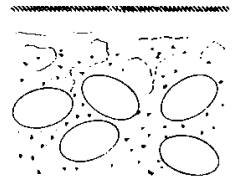

6

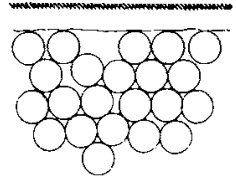

$4 \mathrm{a}$

FIG. 1. Interaction of a foreign material with blood. 1: Exposure of blood to a foreign material. 2: Adsorption of proteins from the blood onto the foreign material. 3: Adhesion of platelets to the adsorbed protein layer. 4: Release of ADP and other platelet constituents. Formation of a platelet aggregate. 5: The coagulation process is started on the surface of the aggregating platelets. Formation of an insoluble fibrin network. 6: Individual platelets lose their integrity and fuse with each other. Fibrin strands with entrapped cells from the blood form a red thrombus. 4a: Formation of a white thrombus by aggregating platelets. la: The coagulation process is started by activation of factor XII on the foreign surface. lb: Thrombin is formed during the coagulation process, resulting in platelet aggregation.

adhesion of platelets in these cases can be explained by assuming that the adsorbed glycoproteins fibrinogen and $\gamma$-globulin interact with platelets. In the model of Lee and Kim [10, 11], a glycosyl transferase enzyme located in the platelet membrane forms a complex with a glycoprotein containing incomplete heterosaccharides (e.g., fibrinogen) when adsorbed on a foreign surface. On the other hand, reduced platelet adhesion has been reported for polymers, which adsorb relatively large amounts of albumin, such as some block copolyether urethanes [12].

Little is known about the relation between adsorbed proteins and the surface activation of intrinsic coagulation. Preliminary in vitro experiments carried out in our laboratory indicate that this activation is dependent on the type of preadsorbed protein and the surface properties of the material (Feijen et al. [13]). These results are listed in Tables I and II. As can be seen from Table I, albumin-coated surfaces (glass, cuprophane, polystyrene) showed longer plasma coagulation times than surfaces which were coated with fibrinogen or $\gamma$-globulin. This indicates that polymers which show a preferential adsorption of albumin do not only cause a reduced platelet ad- 
TABLE 1

Effect of Preadsorption of Proteins onto Different Surfaces on the Coagulation Times of Plasma ${ }^{a}$

\begin{tabular}{|c|c|c|}
\hline Material & $\begin{array}{c}\text { Relative coagulation } \\
\text { time in } 8\end{array}$ & $\begin{array}{l}\text { Number of } \\
\text { experiments }\end{array}$ \\
\hline polystyrene & 100 & 10 \\
\hline albumin & $114-120$ & 9 \\
\hline$r$-globulin & $104-111$ & 9 \\
\hline fibrinogen & $97-100$ & 6 \\
\hline cuprophane & 100 & 10 \\
\hline albumin & $115-119$ & 3 \\
\hline$\gamma$-globulin & $103-107$ & 3 \\
\hline fibrinogen & $99-103$ & 3 \\
\hline glass & 100 & 10 \\
\hline albumin & $121-130$ & 3 \\
\hline r-globulin & $103-108$ & 3 \\
\hline fibrinogen & $98-105$ & 3 \\
\hline
\end{tabular}

${ }^{a}$ Experimental conditions: bovine proteins, bovine plasma, Lindholm cell [27], $37^{\circ} \mathrm{C}$; adsorption of protein $2.5 \mathrm{hr}\left(0.25 \mathrm{~g} \mathrm{liter}^{-1}\right)$.

hesion but also delay the contact activation of intrinsic coagulation. In order to synthesize new polymers which preferentially adsorb albumin from the blood and which may be antithrombogenic, it is important to get more insight into the processes which determine protein adsorption.

\section{THROMBORESISTANT COATINGS}

An important method to obtain more thromboresistant polymers is the modification of polymer surfaces by coating them with specific compounds which reduce platelet adhesion and/or blood coagulation. Well-known examples are heparin-bonded surfaces [14]. Reduced platelet adhesion on such surfaces, mentioned in the literature $[15,16]$, may be explained by a reduced fibrinogen adsorption, which has also been reported [15, 17]. Moreover, antithrombin III (AT-III) is adsorbed from plasma by these surfaces and the resulting AT-III-coated surface is capable of binding thrombin and other activated coagulation factors $[18,19]$. 
TABLE II

Effect of Preadsorption of Albumin onto Different Surfaces on the Coagulation Time of Plasma ${ }^{a}$

\begin{tabular}{|c|r|c|}
\hline Material & $\begin{array}{r}\text { Relative coagulation } \\
\text { time in } 8\end{array}$ & $\begin{array}{c}\text { Number of } \\
\text { experiments }\end{array}$ \\
\hline $\begin{array}{c}\text { cuprophane } \\
\text { albumin }\end{array}$ & 100 & 10 \\
polystyrene & $115-119$ & 3 \\
albumin & $119-126$ & 10 \\
glass & $64-69$ & 3 \\
albumin & 63 & 10 \\
\hline
\end{tabular}

${ }^{2}$ Experimental conditions: bovine protein, bovine plasma, Lindholm cell, $37^{\circ} \mathrm{C}$; adsorption of protein $2.5 \mathrm{hr}\left(0.25 \mathrm{~g}\right.$ liter $\left.^{-1}\right)$.

However, part of the antithrombogenic properties of heparin-bonded surfaces can be explained by the fact that heparin leakage can occur [14]. Therefore it is difficult to distinguish between the contribution of dissolved heparin and of surface-bound heparin to the nonthrombogenicity of heparinized surfaces. In an attempt to produce more stable thromboresistant surfaces we have coated (hydrophobic) polymers with a synthetic polyelectrolyte $(\mathrm{P})$ containing sulfamate and carboxylate groups:

$$
-\left[\begin{array}{ccc}
\mathrm{CH}_{2}-\mathrm{CH}_{3}-\mathrm{C}-\mathrm{CH}_{2} \\
\mathrm{CH}_{\mathrm{NH}}^{\mathrm{C}} & \mathrm{CH}_{\mathrm{ONa}} \\
\mathrm{SO}_{3} \mathrm{Na} & \mathrm{O}
\end{array}\right]-
$$

In recent publications from our group the synthesis $[20,21]$ and anticoagulant properties $[22,23]$ of $\mathbf{P}$ have been described. It resembles heparin in many aspects. It is an antithrombin and its action is also stimulated by, or is dependent on, a cofactor (presumably AT-III) present in the blood plasma. Like heparin, $\mathbf{P}$ can be linked ionically to a polymer surface by means of the adsorptive coupling agent tridodecylmethylammonium chloride (TDMAC). As $P$ has an approximate molecular weight of 750,000 , the number of ionic surface bonding sites per molecule is much larger than in 
heparin (MW 6,000-20,000). Therefore it was expected that the stability of ionic-type surface coatings with $\mathbf{P}$ should be superior to the complexes of heparin and TDMAC, and that elution of P from the coatings should be negligible. This was confirmed by desorption experiments carried out by Froehling [24]. He found that in the presence of $0.15 \mathrm{M} \mathrm{NaCl}$ or bovine plasma no ${ }^{125}$ I-labeled $P$ was eluted from PVC treated with TDMAC.

PVC films, coated with the TDMAC complex of $P$, showed little or no platelet adhesion when exposed to freshly drawn human blood. Quantitative data concerning the adhesion of blood platelets to glass, polystyrene, PVC and P-coated PVC are listed in Table III. These data were obtained from experiments in which the blood was slowly pumped through two parallel flow cells previously filled with saline (thus avoiding blood-air interfaces). One cell contained a reference material, while the other one contained the test material. The cells are nearly identical with the test cell used by Mason et al. $[8,9,25]$. An exploded view of one of our cells is shown in Figure 2. Platelet adhesion and fibrin deposition on the test materials were studied with the aid of a scanning electron microscope (SEM). Activation of intrinsic coagulation was measured by means of a modified PTT test. Experimental details are published elsewhere [26]. SEM photographs of the various materials which had been exposed to blood are shown in Figures 3-6.

Due to the chemical similarity of $\mathbf{P}$ and heparin it is likely that P-coated PVC and heparin-bonded surfaces act in a similar way toward platelets, e.g., via a reduced fibrinogen adsorption. Although we may assume that the complex of $\mathrm{P}$ and TDMAC consists of completely neutralized polyelectrolyte, it is possible that the complex is partly dissociated in blood under the influence of plasma salts. In this way, parts of the $\mathbf{P}$ molecules remain bound to the sur-

TABLE III

Adhesion of Platelets and Activation of Intrinsic Coagulation ${ }^{\mathrm{a}}$

\begin{tabular}{|c|c|c|}
\hline Material & $\begin{array}{c}\text { Adhering platelets } \\
\text { on } 0.01 \mathrm{~mm}^{2}\end{array}$ & $\begin{array}{c}\text { PTT - value } \\
(\text { polystyrene }=1008)\end{array}$ \\
\hline glass & $(20-59)$ & 66 \\
\hline polystyrene & $(8-21)$ & 100 \\
\hline PVC, uncoated & $(13-18)$ & 100 \\
\hline PVC / P-TDMAC & $(0-5)$ & 105 \\
\hline
\end{tabular}

${ }^{\text {a }}$ Experimental conditions: materials in the flow cell were exposed to freshly drawn human blood for $5 \mathrm{~min}$ at $37^{\circ} \mathrm{C}$ (flow rate $1 \mathrm{ml} / \mathrm{min}$ ). 


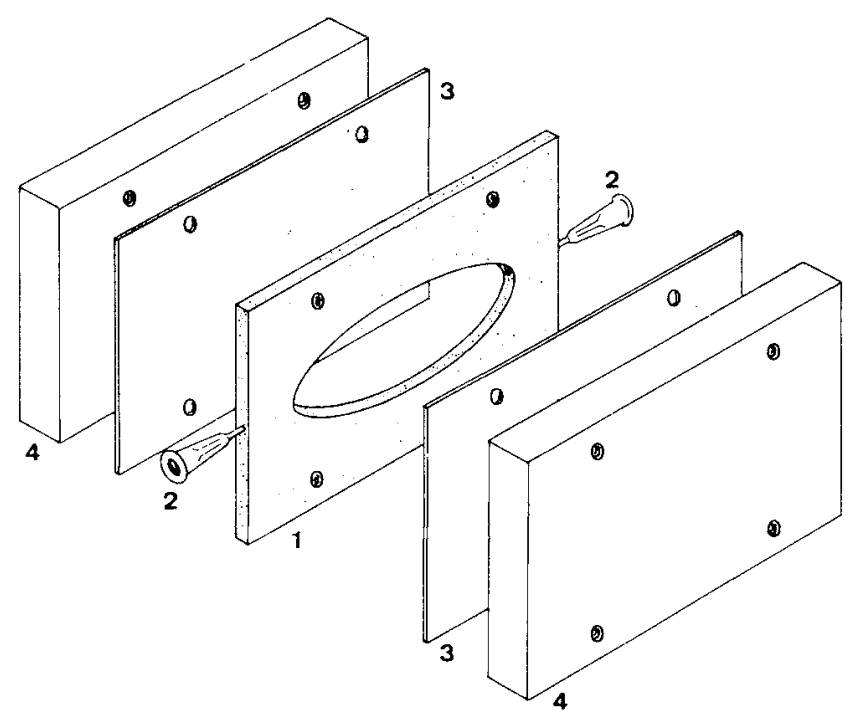

FIG. 2. Exploded view of a flow cell, based on the experimental approach of Mason. 1: Silastic rubber gasket, $3 \mathrm{~mm}$ thick, with elliptical cut out. The axes of the ellipse are 63 to $24 \mathrm{~mm}$. 2: Inlet and outlet of the cell, consisting of cut-off needles (Luer P), $1.20 \mathrm{~mm}$ thick. 3: Sheets of the material to be tested. 4: Lucite support blocks. The holes in one support block are treaded internally; the other block has plain holes. - The cell is assembled with the aid of four bolts.

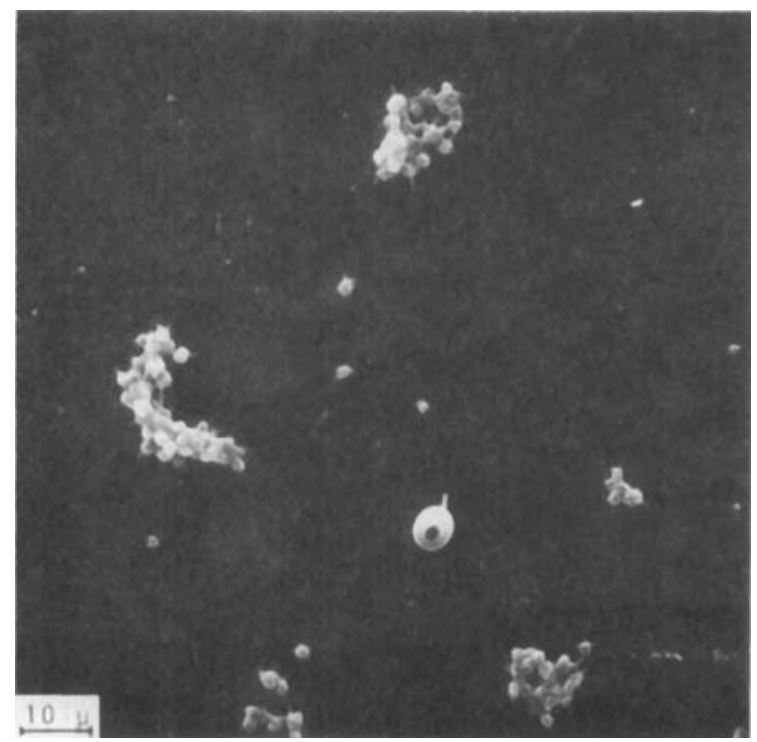

FIG. 3. Glass exposed to blood in the flow cell for $5 \mathrm{~min}$ (flow rate $1 \mathrm{ml} / \mathrm{min}$ ). Single platelets and aggregates adhere to the surface. A single erythrocyte is also present. 


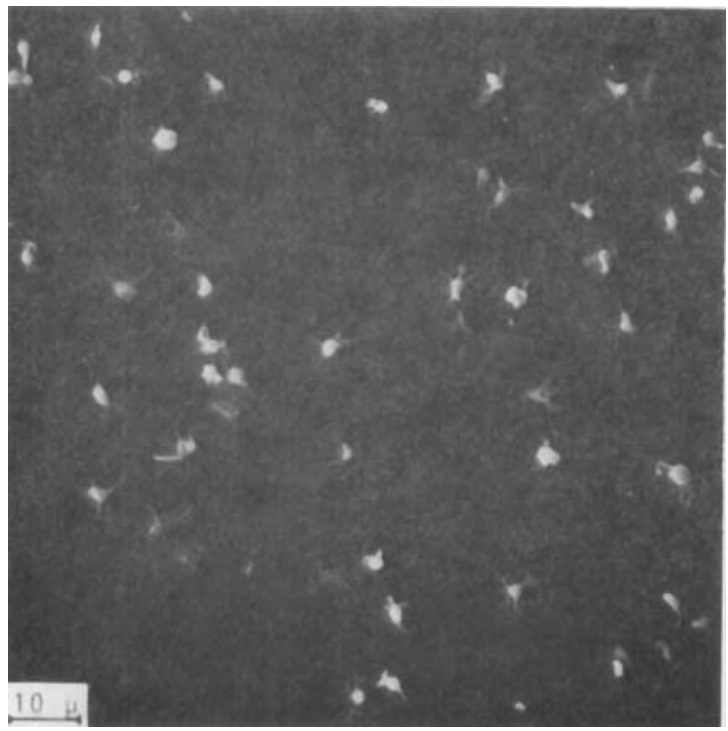

FIG. 4. Polystyrene exposed to blood in the flow cell for $5 \mathrm{~min}$ (flow rate $1 \mathrm{ml} / \mathrm{min}$ ). Numerous platelets, both single and in small aggregates, adhere to the surface.

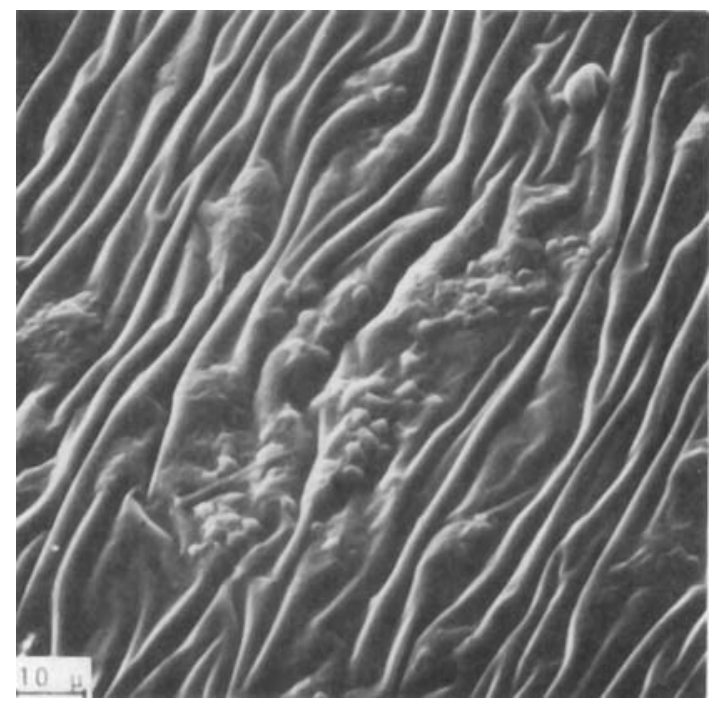

FIG. 5. PVC exposed to blood in the flow cell for $5 \mathrm{~min}$ (flow rate $1 \mathrm{ml} / \mathrm{min}$ ). Many aggregated platelets with pseudopods adhere to the irregular surface. 


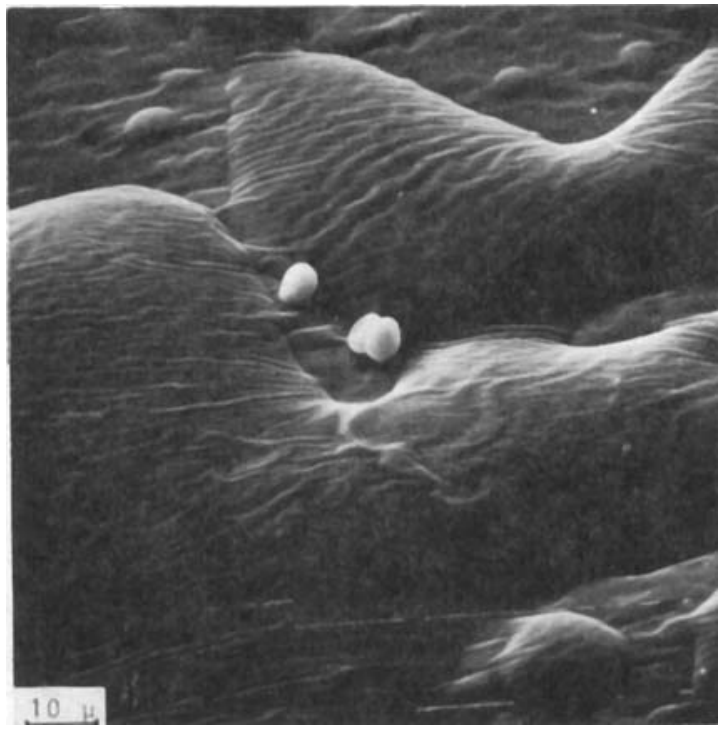

FIG. 6. PVC coated with a complex of $P$ and TDMAC. The surface has been exposed to blood in the flow cell for $5 \mathrm{~min}$ (flow rate $1 \mathrm{ml} / \mathrm{min}$ ). Three erythrocytes adhere to the surface; no platelets are present upon this surface area.

face, while other parts of these molecules extend into the liquid. This results in a surface layer of quasidissolved polyelectrolyte. Thus the negatively charged polyelectrolyte may account for the reduced platelet adhesion.

Froehling [24] also found that P-coated PVC delays the contact activation of bovine plasma and he showed that AT-III is adsorbed and activated on the surface coating. On the other hand, we measured an enhanced coagulation of human plasma in coated PVC and silicon rubber tubes compared to the uncoated tubes. This may explain the fact that the PTT value for blood, which had been passed through the flow cell, is not relatively high in the case of P-coated PVC (Table III). However, the PTT values from Table III may have been influenced by a considerable activation of factor XII, due to the syringe and parts of the cell, especially its narrow inlet and outlet. A further systematic study of the thromboresistant properties of P-coated surfaces, including in vivo experiments, will be carried out in the near future.

The members of the biomaterials section of our laboratory are gratefully acknowledged for their contribution to this paper.

\section{REFERENCES}

[1] J. Feijen, in Proceedings of the Second Strathclyde Bioengineering Seminar "Artificial Organs," August 18-20, 1976, Glasgow (Scotland), R. M. Kenedi, J. M. Courtney, J. D. S. Gaylor, and T. Gilchrist, Eds., MacMillan, London, 1977, p. 235. 
[2] J. Feijen, T. Beugeling, A. Bantjes, and C. Smit Sibinga, in Cardio-circulatory Analysis of Aspects of Diagnosis, Assist. Therapeutic and Prosthetic Devices, Vol. IV, W. J. Yang, Ed., Karger, Basel, 1979, forthcoming.

[3] P. N. Walsh, Blood, 43, 597 (1974).

[4] M. B. Zucker and L. Vroman, Proc. Soc. Exp. Biol. Med., 131, 318 (1969).

[5] M. A. Packham, G. Evans, M. F. Glyn, and J. F. Mustard, J. Lab. Clin. Med., 73, 686 (1969).

[6] D. J. Lyamn, K. G. Klein, J. L. Brash, and B. K. Fritzinger, Thrombos. Diathes. Heamorrh. (Stuttgart), 23, 120 (1970).

[7] R. G. Mason, M. S. Read, and K. M. Brinkhous, Proc. Soc. Exp. Biol. Med., 137, 680 (1971).

[8] R. G. Mason, R. W. Shermer, and N. F. Rodman, Am. J. Pathol., 69, 271 (1972).

[9] R. G. Mason, R. W. Shermer, W. H. Zucker, and K. M. Brinkhous, in Erythrocytes, Thrombocytes, Leucocytes, E. Gerlach, K. Moser, E. Deutsch, and W. Wilmanns, Eds., Thieme, Stuttgart, 1973, p. 263.

[10] R. G. Lee and S. W. Kim, J. Biomed. Mater. Res, 8, 251 (1974).

[11] S. W. Kim, R. G. Lee, H. Oster, D. Colemen, J. D. Andrade, D. J. Lentz, and D. Olsen, Trans. Am. Soc. Artif. Intern. Organs, 20, 449 (1974).

[12] S. W. Kim and D. J. Lyman, Appl. Polym. Symp., 22, 289 (1973).

[13] J. Feijen, T. Beugeling, and A. H. J. Tijhuis, unpublished results.

[14] R. I. Leininger, J. P. Crowley, R. D. Falb, and G. A. Grode, Trans. Am. Soc. Artif. Intern. Organs, 18, 312 (1972).

[15] M. Klings, A. L. Adams, and L. Vroman, Thrombosis Res., 1, 507 (1972).

[16] A. Rembaum, S. P. S. Yen, M. Ingram, J. F. Newton, and C. L. Hu, Biomater. Med. Devices Artif. Organs, 1, 99 (1973).

[17] G. E. Stoner, S. Srinivasan, and E. Gileadi, J. Phys. Chem., 75, 2107 (1975).

[18] E. Thaler and G. Schmer, Trans, Am. Soc. Artif. Intern. Organs, 20, 516 (1974).

[19] P. S. Damus and G. A. Wallace, Biochem. Biophys. Res. Commun., 61,1147 (1974).

[20] L. van der Does, J. Hofman, and T. E. C. van Utteren, J. Polym. Sci. Polym. Lett. Ed., 11,169 (1973).

[21] L. van der Does, T. Beugeling, P. E. Froehling, and A. Bantjes, J. Polym. Sci. Polym. Symp. 66, 337 (1979).

[22] T. Beugeling, L. van der Does, A. Bantjes, and W. L. Sederel, J. Biomed. Mater. Res, 8, 375 (1974).

[23] T. Beugeling, L. van der Does, B. V. Rejda, and A. Bantjes, in Biocompatibility of Implant Materials, D. Williams, Ed., Sector, London, 1976, p. 187.

[24] P. E. Froehling, Antithrombogenic Surface Coatings based on a Synthetic Heparinoid Polyelectrolyte, Thesis, Twente University of Technology, Enschede, The Netherlands, 1977.

[25] R. G. Mason, Bull. N. Y. Acad. Sci., 48, 407 (1972).

[26] T. Beugeling, J. Feijen, A. H. J. Tijhuis, P. E. Froehling, M. A. de Jongh, M. Looze-van Iperen, and A. Bantjes, Proceedings European Society for Artificial Organs, November 21-24, 1976, E. S. Bücherl, Ed., Westkreuz, Berlin, 1978, p. 76.

[27] R. G. Mason, Biomater. Med. Devices Artif. Organs, 1, 131 (1973). 